\title{
POPULAR PARTICIPATION IN A LOCAL HEALTH COUNCIL: LIMITS AND POTENTIALS
}

\author{
Juliano de Amorim Busana1, Ivonete Teresinha Schulter Buss Heidemann², Águeda Lenita Pereira \\ Wendhausen ${ }^{3}$
}

\begin{abstract}
${ }^{1}$ M. Sc. in Nursing. Nursing Graduate Program, Universidade Federal de Santa Catarina (UFSC). Florianópolis, Santa Catarina, Brazil. E-mail: julianobusana@hotmail.com

2 Ph.D. in Public Health Care Nursing. Associate Professor of the Department of Nursing and the Nursing Graduate Program of the UFSC. Florianópolis, Santa Catarina, Brazil. E-mail: ivonete.heidemann@ufsc.br

${ }^{3}$ Ph.D. in Nursing. Professor of the Master's Program in Health Care and Work Management and of the Nursing Undergraduate Program of the Universidade do Vale do Itajaí. Itajaí, Santa Catarina, Brazil. E-mail: aguedalenita@gmail.com
\end{abstract}

\begin{abstract}
This qualitative study aimed to analyze the potential and limits of popular participation in local health councils through Paulo Freire's research itinerary. Eleven members of a local health council of a municipality in the state of Santa Catarina participated in this study. There were five culture circles and research revealed six themes: possibilities for the practice of citizenship; establishment of an educational space; intention to make decisions that represent the collective; lack of knowledge regarding the council's responsibilities; lack of community participation; and discredit. Results point to the need to understand the roles of the counselors and of the local health councils to strengthen actions of health promotion. Based on ideas and exchanges of experiences among the council participants, we noticed the creation of dialog zones and the understanding of the exercise of power, which strengthened dialog in these public spaces. DESCRIPTORS: Consumer participation. Strategies. Health councils. Health promotion. Unified health system.
\end{abstract}

\section{PARTICIPAÇÃO POPULAR EM UM CONSELHO LOCAL DE SAÚDE: LIMITES E POTENCIALIDADES}

RESUMO: Estudo qualitativo que objetivou analisar os limites e potencialidades da participação popular nos conselhos locais de saúde, por meio do Itinerário de Pesquisa de Paulo Freire. Participaram deste estudo onze conselheiros de um Conselho Local de Saúde de um município de Santa Catarina. Realizaram-se cinco círculos de cultura e a investigação revelou seis temas: Possibilidade de exercício da cidadania; Constituição de um espaço educativo; Intencionalidade de tomada de decisão que represente a coletividade; Desconhecimento das responsabilidades do conselho; Exiguidade de participação da comunidade; e Descrédito. Os resultados apontam a necessidade de compreensão dos papéis dos conselheiros e dos conselhos locais de saúde para fortalecer ações de promoção à saúde. Partindo das reflexões e trocas de experiência junto aos participantes do conselho, percebeu-se a criação de zonas de diálogo e compreensão do exercício do poder pelos participantes, fortalecendo a dialogicidade nestes espaços públicos.

DESCRITORES: Participação comunitária. Estratégias. Conselhos de saúde. Promoção da saúde. Sistema único de saúde.

\section{PARTICIPACIÓN POPULAR EN UNA JUNTA LOCAL DE SALUD: LÍMITES Y FORTALEZAS}

RESUMEN: Este estudio cualitativo tuvo como objetivo analizar el potencial y los límites de la participación popular en los Consejos Locales de Salud, a través del Itinerario de Investigación Paulo Freire. El estudio incluyó once miembros de un Consejo Local de Salud del municipio de Santa Catarina. Habían cinco Círculos de Cultura y de la investigación revelaron seis temas: Probabilidad de ciudadanía; Establecimiento de un espacio educativo; Toma de decisiones la intencionalidad que representa a la comunidad; Desconocimiento de las responsabilidades de lo Consejo; Exigüidad de participación de la comunitaria y Descrédito. Los resultados apuntan a la necesidad de comprender los roles de los concejales y Juntas Locales de Salud para fortalecer las acciones de promoción de la salud basadas en las ideas y el intercambio de experiencias entre los participantes del Consejo se dio cuenta de la creación de zonas de diálogo y la comprensión del ejercicio del poder mediante el fortalecimiento de los participantes al dialogicidad en estas áreas públicas.

DESCRIPTORES: Participación comunitaria. Estrategias. Consejos de salud. Promoción de la salud. Sistema único de salud. 


\section{INTRODUCTION}

The creation of the Unified Health System (Sistema Único de Saúde) [SUS] through Article 196 of the Federal Constitution of 1988 established a new health care policy, guaranteeing health care as a right for everyone and as a duty of the state. To strengthen this process, counter-hegemonic popular movements, represented as emancipatory processes, ended up propelling this creation. ${ }^{1}$

The declaration of the Federal Constitution of 1988 guaranteed the population the right to participate and intervene in health care management. Following this, health councils were created in the three spheres of government. These councils were regulated through the sanction of the laws 8.080 and 8.142 of 1990 . These laws concerned the idea of universal access as the basis of health care policy, which at that moment was under construction in the guidelines of the SUS (The Unified Health System, as per its acronym in Portuguese), changing health care services and therefore allowing an attempt to substitute the hegemonic and biomedical model, which prioritized individual curative actions instead of those that promoted health and collectivity. ${ }^{1}$

The SUS has popular participation as one of its principles. It is understood as the many actions that various social forces develop to influence formulations, executions, supervisions, and evaluations of public policies and basic services in the social field, and it is part of the health promotion field. ${ }^{2}$

This attracts attention as having high political and social importance, because it guarantees popular participation in the process of control and formulation of public health policies. In Brazil, social control considers popular participation in the decision process of public health policies and also considers control of state actions, thus showing the sizable responsibility attributed to society for the improvement of the community's quality of life. ${ }^{3}$

It was within this scenario of municipalization and decentralization of health care, promoted by the Federal Constitution of 1988, that municipal health councils took on responsibility for supervising and deliberating the public health policies of municipalities. Starting in 1994, with the creation of the Family Health Program (FHP) and Ordinance GM N. 648 / 2006, which regulates the Family Health Strategy (FHS), the ideal of reorganizing primary health care with a focus on community and family considered participation as its main element, combatting the population's health risks and social inequalities, and reaffirming health as a universal right and a duty of the state. ${ }^{4}$ After the implementation of FHS with multi-professional teams, its priority was to establish a connection with the community in its accompanying territory, with the goal of securing an agreement of coresponsibility between multi-professional teams and the community. ${ }^{5}$

Although the local health councils (LHCs) were not foreseen in Law 8.142 of 1990, the fifth paragraph of its first article defines that health conferences and health councils will have their organization and operational rules determined by their own ordinance, approved by the corresponding council. Therefore, a precedent is set for social control to happen in environments outside of the three spheres of government. With this, LHCs became an ideal space for the expression of the needs of the community, representing the democratic legitimacy of popular participation at its basis, because it is a less formal and bureaucratic space. ${ }^{6}$

At that moment, after all of the struggles and achievements of social movements, the citizens acquired the duty and the right to participate. They had the role of participating in the decisionmaking process of health care management with the goal of improving individual and collective quality of life, because it is a space for the promotion of social self-responsibility, with the aim of receiving co-responsibility for the actualization of public projects and programs that meet the community's needs. Thus, it is in the health council that these questions must be debated. ${ }^{7}$

Because of this dynamic, the role of the local health council and, as consequence, of social control is to be the basis for the strengthening of primary health care, which was conceptualized by the FHS. This concept is based on the perception that individuals who use health care services have more legitimacy to supervise and monitor said services, and are able to participate in the deliberations for its guidelines. ${ }^{4}$

The importance of promoting the empowerment of the people can be noticed in one of the concepts of health promotion that is backed by the Ottawa Charter, with the objective of building a new citizenship and seeking collective well-being. Empowerment becomes imperative in the process of social control performed by the community in search of improvements in quality of life. With this 
in mind, support for community autonomy may serve as a means for the construction of citizenship as well as co-responsibility for the improvement of the community's quality of life and for popular participation. ${ }^{8}$ Empowerment is understood as a health process focused on changes in the reality and production of health and healthy individuals, which favors the participation of people, organizations, and community and expands their control over political actions for the improvement of life conditions. $^{9}$

In the logic of health promotion, it is mandatory to collaborate with community empowerment through environments of exchange and raising awareness in order to practice intervention in community spaces. In this sense, the LHCs became spaces for learning and for practicing citizenship. ${ }^{10}$ Citizenship, seen as "an act of solidarity" and "love for your neighbor," seeks the enforcement of rights in conjunction with a provider state, in which all individuals are equal under its protection and health care is a consumer good and a right for all. ${ }^{11}$

On the other hand, managers are disengaged from the conditions for good performance of the councils' functions and society has a reluctance to participate in them, leaving managers with the responsibility to educate and stimulate counselors. This attitude leads to the sensation that the role of directing and forming the council is in the hands of the managers and, unfortunately, this reasoning has spread throughout many councils and in many municipalities, where counselors become assistants to the managers, thus following their directions. $^{12}$

In this scenario, it is important to understand in which practices those who actively participate in decision-making processes at the level of councils are based, unveiling the limits and potentials of this participation through the eyes of the representatives in the local health councils. To that end, we ask: What are the limits and potentials of popular participation that are considered essential for the representatives of a local health council? Therefore, the aim of this study was to understand the limits and potentials of popular participation for the representatives of a local health council.

\section{METHOD}

Qualitative research was developed through Paulo Freire's research itinerary, in conjunction with a CLS of a municipality in the state of Santa Catarina, Brazil. Freire's research itinerary guided the gathering and analysis of data and considered the following stages: thematic investigation; coding; decoding; and critical unveiling.

The above-mentioned municipality was created by Law N. 164 of April 4, 1859. According to the 2010 census, the demographic group is predominantly urban, with around 182,000 residents. Azorean immigrants were its primary settlers. The Azorean culture may be visualized through the architecture, which is preserved in many places around the city and also through the Portuguese celebrations and fishing activities. The economy is strongly supported by the port, by logistics companies, by fishing, and by wholesale fuel commerce. ${ }^{13}$

In 2005, Municipal Law 4.376/05 established and regulated the LHCs in the municipality, which restructured the representations of counselors at the municipal level and the guarantee of popular participation through the primary health care units. The eight existing LHCs are linked to the family health units of neighborhoods in the municipality.

The composition of the council that participates in this study was based on information received from the president of the Municipal Council of Health. We opted for the one that was considered the most representative and active in the municipality. The number of people who attend the meetings of the chosen local council is variable, consisting of a group of 10 counselors (necessary in the minimum composition of $70 \%$ users and $30 \%$ representatives of the health care units, according to internal ordinance) at the time of this research. Therefore, the monthly meetings have a certain variation in attendance, with no mandatory formal minimum or maximum number of attendants.

As inclusion criteria for this study's subjects, we considered all attendants at the meetings. Subjects who did not accept to sign a free and informed consent form would be excluded.

The culture circles were composed of meetings with up to 11 subjects, among users and health care professionals, who favored and promoted dialog as an effective communication strategy, generating countless questions regarding the realities of these subjects in the local health council. The culture circles generated themes for analysis and were learning spaces that promoted action and thought among all involved. ${ }^{14}$

In total, five culture circles were promoted in the period between the months of June and September 2013, each lasting around two hours. 
We used a field diary to investigate the themes, where we annotated observations that would be conducive to the stages of Freire's itinerary and that worked as guides for dialog and analysis of themes during the culture circles. We also used an audio recorder and a video camera to register information in full, which was previously authorized by the participants.

When proposing the formation of culture circles, the researchers first attended meetings of the local health council and explained the goals of the research and the Freirian methodology, which enabled the recognition of the social context of the chosen council and established the first culture circle.

In the second and third culture circles, the generating themes were investigated from some stimulating questions: what are the participation practices in the LHC? What are the difficult points in participating in the LHC? What are the easy points in participating in the LHC?

From these questions we highlighted common ideas among the participants and called them "central themes." Starting from the experiences and background of the group, we coded, decoded, and closely examined these central themes throughout the culture circles.

The coding and decoding stages happened in the fourth culture circle, and the critical unveiling stage happened in the fifth and last culture circle.
The critical unveiling enabled the analysis and addressing of the coded and problematized themes from the comprehension of popular participation. In this last culture circle, we conducted a group evaluation of the shared experience for this study.

The ethical aspects that guided this research observed Resolution n. 466/12 of the National Health Council, which approves and regulates research with human beings. The Ethics Committee of the Universidade Federal de Santa Catarina evaluated the study under protocol number 393.516. The study's participants signed two identical copies of a free and informed consent form, keeping one copy for themselves and one for the researchers.

A structured questionnaire gathered the information that distinguished the participants. The participants were coded by the letter $U$ (for user) and $\mathrm{P}$ (for family health professional), followed by a number that corresponded to the order of participation in the circles.

\section{RESULTS}

This study's results are presented according to discussions that resulted from the development of the stages of Freire's itinerary, through generating themes, coding, decoding, and critical unveiling of reality, followed by reflections that the group performed during the research process.

\section{Chart 1 - Characteristics of the counselors. Itajaí, Santa Catarina, 2013}

\begin{tabular}{|c|c|c|c|c|c|c|}
\hline & Age & Gender & Education & Professional situation & Reasons & Length of participation \\
\hline U1 & 42 & M & $\begin{array}{l}\text { Completed middle } \\
\text { school }\end{array}$ & Self-employed & Own initiative & Less than 1 year \\
\hline U2 & 65 & M & $\begin{array}{l}\text { Completed middle } \\
\text { school }\end{array}$ & Retired & Peer motivation & 5 years \\
\hline U3 & 41 & M & Completed high school & $\begin{array}{c}\text { Private Corporation } \\
\text { employee }\end{array}$ & Own initiative & Less than 1 year \\
\hline U4 & 60 & M & $\begin{array}{l}\text { Did not complete high } \\
\text { school }\end{array}$ & Retired & Own initiative & Less than 1 year \\
\hline U5 & 37 & M & $\begin{array}{c}\text { Completed middle } \\
\text { school }\end{array}$ & $\begin{array}{c}\text { Private Corporation } \\
\text { employee }\end{array}$ & Own initiative & Less than 1 year \\
\hline U6 & 64 & M & $\begin{array}{c}\text { Did not complete } \\
\text { middle school }\end{array}$ & Retired & Own initiative & Less than 1 year \\
\hline U7 & 44 & M & $\begin{array}{c}\text { Stricto Sensu graduate } \\
\text { degree }\end{array}$ & $\begin{array}{l}\text { Self-employed (Physical } \\
\text { educator) }\end{array}$ & Own initiative & 2 years \\
\hline U8 & 34 & $\mathrm{~F}$ & $\begin{array}{l}\text { Completed higher edu- } \\
\text { cation }\end{array}$ & Self-Employed (Architect) & Peer motivation & Less than 1 year \\
\hline U9 & 45 & $\mathrm{~F}$ & Completed high school & Merchant & Peer motivation & Less than 1 year \\
\hline P1 & 57 & $\mathrm{~F}$ & $\begin{array}{l}\text { Completed higher edu- } \\
\text { cation }\end{array}$ & Public sector nurse & Own initiative & 8 years \\
\hline P2 & 45 & $\mathrm{~F}$ & $\begin{array}{l}\text { Completed higher edu- } \\
\text { cation }\end{array}$ & Public sector physician & Own initiative & 1 year and 6 months \\
\hline
\end{tabular}


The first culture circle occurred with the attendance of 11 representatives and had the goal of raising the subjects' awareness of the importance of the theme and of continuous reflection about it, in addition to presenting the proposal and the study's objectives. In this meeting, participants read and signed the free and informed consent form. We also asked for information that would distinguish the subjects and reveal the reasons that led them to participate as council representatives. For this activity, we used a structured questionnaire.

In the second and third culture circles, both with nine representatives in attendance, we proposed a reflection about the council and its participation, in addition to the strengths and weaknesses that permeate the processes. This provided 39 generative themes.

In the third culture circle, we asked the participants to express "ease of participation in the LHC" and "difficulties in participation in the LHC." This talk generated themes that were related to the council's reality, with special attention paid to those related to the pleasant feeling of participating and to the intention and predisposition to make decisions that represented collectivity within the sphere of potentialities of the LHC.

The themes related to the limits of participation in the LHC converged to the understanding that there is a lack of motivation for collective decision-making on the part of the community; a lack of knowledge regarding the attributions and responsibilities of a council, as well as those of its members; a lack of confidence on the part of the community; limitations in terms of the council's procedures and low decision-making power; and difficulties related to the appropriation of knowledge regarding the council, among other themes that resulted in the coding and decoding stage following the counselors' reflection.

In the fourth culture circle we coded and decoded the following themes in relation to potentials: possibilities of practicing citizenship, establishment of an educative space, and intention in decision-making that represents the collective (these three related to the potentials of counselors participation); and lack of knowledge regarding the responsibilities of the council, lack of participation from the community, and lack of credit (these three related to limits to participation). Through the participants' reports, the reflections pointed to the need to qualify group participation through activities that favor everyone's comprehension of the theme and that offer consistent support from the literature and legislation regarding the performance of roles and persuasive possibilities for decision-making.

Therefore, regarding strengths, facilities, or potentials for participation in the LHC, the representatives claimed that the meetings and discussions improved their self-esteem and made them feel useful and as essential parts of a collective. The meetings were significant precisely because they were spaces for exchange and socialization of difficulties, favoring learning and countless possibilities for effecting citizenship.

In this context, the participants believed that participating as representatives of a council was conducive to uniting strengths and acting for the common good, guided by movements of empowerment, even if unconsciously. Participants also mentioned the group's desire to propose the establishment of an education space in each meeting, gradually creating new and better actions through an increasing integration among its members, which was reflected in actions already in place and in other activities developed in the LHC that was being studied.

The interest in learning, in information is fundamental and the beginning of everything is the desire to participate. From that, things will happen naturally [...] (P1).

The fact that the meetings are planned and organized to stimulate the participation of all was seen as one of the positive aspects.

There is the possibility to participate in other situations, with the LHC acting as an entrance to broader participation in other public spaces for decision making. The representatives also conveyed that the group has a strong intention to make decisions that represent the collective.

I used to be part of the participative budget, so I learned a lot there, too. We have to get involved to know what's going on. People are very critical, but have no interest in actually knowing what's happening. They don't participate [...] (U1).

Structural factors, such as the location in which meetings happen and how close it is to where everybody lives, are also aspects that facilitate the participation of the LHC's representatives.

Through dialogs it was equally possible to understand the many difficulties perceived by 
representatives. Lack of knowledge regarding the council's responsibilities, its limits, and possibilities are obstacles to participation. In this theme, the lack of information on the part of the population in general regarding councils, a lack of interest, and the absence of most of the community from the discussions have a negative effect, weakening the LHC's performance.

SUS is problematic, but it is our biggest asset; it has to improve and become something of value. Not many health insurance plans have 100 million clients who don't pay directly [...] (U7).

Difficulties in working with computers or searching the Internet, in addition to difficulties in understanding the language used in books regarding the theme, and in legislation regarding councils, are other aspects that are equally negative for participation in the LHCs.

I would consider interesting to have a textbook about the council that we could study. I took many courses and I have all textbooks at my house. Sometimes I read one of them [...] (U1).

For some participants, lack of education in the field of health was understood as a difficulty, especially because it is challenging for them to broadly understand available health care actions, treatments, medication, etc. Some representatives talked about the fact that participation in the council is an activity that needs to be coordinated with work and family, from the perspective of time, which reduces community participation.

I love to participate, but I'm working and I don't have a set schedule. I never missed a meeting because of laziness or lack of will, but because of work [...] (U3).

The lack of results from some of the actions of the LHC was negatively perceived by the participants, because it resulted in disbelief, discredit, and demotivation by the community in relation to the service.

We fought for a daycare center and it is being built. We achieved many things. Small stuff that we didn't use to have [...] (U3)

There is a collective lack of interest [...] (P1).

Thus, the establishment and strengthening of the SUS are still challenges, that is, potentials and limits that become demands, sometimes for strengthening, sometimes for intervention. The experience and dialog with representatives created a space for problematization and a search for alternatives related to the resolution of problems in the community.

\section{ANALYSIS AND DISCUSSION}

Health councils become spaces for the articulation of policies in the field of health, in the actions of the state, and in the practice of citizenship, with the intention of maximizing social control in the management of the SUS. With this in mind, such scenarios are becoming more solid through laws, ordinances, and proposals by the federal government that point to the importance of health councils as spaces for the practice of social control and the strengthening of citizenship. ${ }^{15}$

It is through popular participation in health councils, in conjunction with the desire to conduct political and social transformations, that this process will become an essential tool for the development of individual and collective empowerment. Such processes affect the status quo while promoting political conscience and autonomy for decision making. ${ }^{16}$

In this scenario, we call special attention to the institutionalization of spaces for community participation in the daily life of health care services, through guaranteeing participation in the plans to handle prioritized problems, execution, and evaluation of actions, a process in which popular participation must be guaranteed and encouraged. ${ }^{3}$

Because the SUS is the first public policy in Brazil to constitutionally include popular participation as one of its principles, this not only reaffirms the practice of social control over health care practices, but also confirms the possibility in its legal definition of its practice through other institutionalized spaces, in addition to those recognized by Organic Health Law n. 8.142/90, the councils, and health care conferences. We also call attention to public audiences and other mechanisms for giving a hearing to the population, users, and social workers. ${ }^{3}$

In addition, Organic Health Law n. $8.080 / 1990$ establishes in article 12 the creation of intersectoral commissions subordinate to the $\mathrm{Na}$ cional Health Council, with the goal of articulating public policies that are important for health, and Law n. 8.142/1990 addresses social participation in the SUS. It specifies that popular participation is included in all spheres of the SUS's management, thus legitimizing the interests of the population in the practice of social control. ${ }^{17}$

The CLSs are not directly responsible for changes in the basis of public management, but they contribute to the meaning of public health 
care policies and the democratization of the connections between communities and municipal public management, because it is in the very existence of the CLSs that social control is practiced in the field of participative management. ${ }^{18}$

One of the weak points noted by the counselors was the lack of belief in the LHCs due to frustrations resulting from the lack of results. Special attention was called to the fact that, in certain situations, management does not accept the council's deliberations, pre-defining or influencing task assignment in meetings or deliberations, using strategies such as an excess of technical jargon to obstruct understanding on the part of the counselors, avoiding political discussions, coopting counselors, etc. ${ }^{19}$

Popular participation promotes social control and must establish councils not as bureaucratic spaces for the authentication of public health policies, but as spaces to share management through discussion, encouraging the understanding of health care as a human right. In this sense, in order to achieve real popular participation, it is necessary to practice citizenship fully and, especially, to encourage a desire on the part of management to make spaces available in which it is possible to question the established order..$^{15}$ Therefore, this scenario may be changed, encouraging popular participation and an effective practice of citizenship.

An excellent method to enable these changes is through adoption of the emancipatory pedagogy process proposed by Freire, in which empowerment becomes a way to encourage individuals to make decisions related to the improvement of their lives. Health promotion becomes influenced because of Freire's concepts, because he defends the emancipation of individuals as an essential tool for changes in the community. Therefore, for Freire, it is important to help individuals help themselves, placing them on a more autonomous and analytical trajectory in terms of their own lives, ${ }^{20}$ especially because popular participation is one of the strategies for health promotion and has as its objective the establishment of autonomy for the population to improve their own quality of life.

In addition, popular participation that seeks individual and collective empowerment is part of perspectives that are both psychological (individual) and social (collective). Psychological or individual empowerment enables individuals to have a stronger sense of control over their own lives, that they are capable of influencing their environment and adapting to it, in addition to developing solidarity mechanisms. Social or collective empowerment seeks to highlight the idea of health care as a process that results from collective struggles for individual rights. It does not deny psychology, but it tries to highlight the importance of fighting the roots of social problems. ${ }^{9,21}$

\section{FINAL CONSIDERATIONS}

In this context, we were able to understand the potentials and weak points related to popular participation in a local health council, because through the use of Freire's itinerary, the LHC's representatives could express their feelings and considerations in relation to the potentials and weak points that exist in popular participation.

It is based on a comprehension of how the LHC works, including its participative practices and especially its potentials and weak points, that the participative process and the quality of participation will be favored, thus achieving the improvement of the community's quality of life. Due to the use of Freire's methodology, it was possible to include researchers in the LHC's reality, bringing about discussions and reflections by the counselors related to their reality. With the noted weak points in mind, such as lack of knowledge regarding the council's real role, low community participation, and discredit, we could verify a desire to change this reality through the counselors' speech.

In relation to potentials, the desire to decide for the collective and to practice citizenship resulted, through the reflections conducted by the counselors in the culture circles, in a proposition to carry out an education session during meetings to collaborate with the counselors' empowerment, thus changing the council's current reality. We suggest the adoption of strategies that stimulate individual and collective empowerment, whose objective is to actualize social participation with a better distribution of power in health promotion spaces, such as local councils.

Through conducting the culture circles focused on stimulating dialog regarding difficulties and potentials, it was possible to notice a conscious link between participants and the demands of the public sphere, which were strengthened in the integrative actions proposed and discussed by all. Conscious attitudes, both from management and from the population, appear to favor the construction of collective meanings for popular participation. Therefore, it was equally possible to understand that participation is intimately re- 
lated to the interests and needs of the people for reasons that make them participate, bringing with them the construction of a personal and collective meaning for actions of stimulus and the practice of citizenship.

After the study was finished, we participated in meetings of the LHC and could notice the effectiveness of using Freire's itinerary to motivate reflection and action in the participants.

\section{REFERENCES}

1. Schwartz TD, Ferreira JTB, Maciel ELN, Lima RCD. Estratégia Saúde da Família: avaliando o acesso ao SUS a partir da percepção dos usuários da Unidade de Saúde de Resistência, na região de São Pedro, no município de Vitória (ES). Ciênc Saúde Coletiva. 2010; 15(4):2145-54.

2. Valla VV. Sobre participação popular: uma questão de perspectiva. Cad Saúde Pública. 1998; 14(2):7-18.

3. Rolim LB, Cruz RSBLC, Sampaio KJAJ. Participação popular e o controle social como diretriz do SUS: uma revisão narrativa. Saúde Debate. 2013; 37(96):139-47.

4. Quandt FL, Fantin AD, Oliveira JR, Kovaleski DF. Análise sobre a participação da comunidade nos Conselhos Locais de Saúde: caso do município de Pomerode. Saude Transf Soc. 2013;4(3):83-90.

5. Mielke FB, Cossetin A, Olschowsky A. O conselho local de saúde e a discussão das ações de saúde mental na estratégia saúde da família. Texto Contexto Enferm. 2012; 21(2):387-94.

6. Souza AV, Krüger TR. Participação social no SUS: proposições das conferências sobre o conselho local de saúde. Rev Saúde Pública. 2010; 3(1):80-96.

7. Blibioteca Virtual em Saúde. Blog Direito Sanitário São Paulo (SP): BVS; 2011 [atualizado 2011 Fev 08; acesso 2013 Dez 10]. Disponível em: http:/ /blogs. bvsalud.org/ds/2011/02/08/a-participacao-dacomunidade-no-sus-nao-ode-ser-um-mito/

8. Heidemann ITSB, Boehs AE, Fernandes GCM, Wosny AM, Marchi JG. Promoção da saúde e qualidade de vida: concepções da Carta de Ottawa em produção científica. Ciênc Cuid Saúde. 2012; 11(3):613-9.

9. Souza JM, Tholl AD, Córdova FP, Heidemann ITSB, Boehs AE, Nitschke RG. Aplicabilidade prática do empowerment nas estratégias de promoção da saúde. Ciênc Saúde Coletiva. 2014; 19(7):2265-76.
10. Kleba ME, Comerlatto D, Colliselli L. Promoção do empoderamento com conselhos gestores de um pólo de educação permanente em saúde. Texto Contexto Enferm. 2007; 16(2):335-42.

11. Longhi JC, Canton GAM. Reflexões sobre cidadania e os entraves para a participação popular no SUS. Physis (Rio J.) [online]. 2011 [acesso 2014 Oct 21]; 21(1):15-30. Disponível em: http://www.scielo. br/scielo.php?script=sci_arttext\&pid=S010373312011000100002\&lng=en

12. Silva VR, Medeiros MR. Conselhos municipais de assistência social: história, fragilidades e possibilidades. Argumentum. 2010; 2(2):163-73.

13. Itajaí [site oficial do município de Itajaí] Itajaí (SC): Prefeitura Municipal; 2013 [acesso 2013 Jul 25]. Disponível em: http://www.itajai.sc.gov.br/

14. Freire P. Educação e mudança. $34^{\mathrm{a}} \mathrm{ed}$. Rio de Janeiro (RJ): Paz e Terra; 2011.

15. Cruz PJSC, Vieira SCR, Massa NM, Araújo TAM, Vasconcelos ACCP. Desafios para a participação popular em saúde: reflexões a partir da educação popular na construção de conselho local de saúde em comunidades de João Pessoa, PB. Saúde Soc. 2012; 21(4):1087-100.

16. Silva CV. A percepção de conselheiros de Conselhos Regionais de Saúde do Distrito Federal acerca dos domínios do empoderamento [dissertação]. Brasília (DF): Universidade de Brasília; Mestrado em Ciências da Saúde; 2013.

17. Ministério da Saúde (BR). As Conferências Nacionais de Saúde: evolução e perspectivas. Brasília (DF): MS; 2009.

18. Miranda JMB, Guimarães SJ. Controle social e conselhos locais de saúde em Teresina: limites e possibilidades. Rev FSA. 2013; 10(3):212-27.

19. Gurgel C, Justen A. Controle social e políticas públicas: a experiência dos Conselhos Gestores. Rev Adm Pública. 2013; 47(2):357-78.

20. Heidemann ITSB. A promoção da saúde e a concepção dialógica de Freire: possiblidades de sua inserção e limites no processo de trabalho das equipes de Saúde da Família [tese]. Ribeirão Preto (SP): Universidade de São Paulo, Escola de Enfermagem de Ribeirão Preto; 2006.

21. Carvalho SR, Gastaldo D. Promoção à saúde e empoderamento: uma reflexão a partir das perspectivas crítico-social e pós-estruturalista. Ciênc Saúde Coletiva. 2008; 13(2):2029-40. 